\title{
Prediction and Selection of the Best Process Parameters to Improve Toughness of Mild Steel Welded Joints
}

\author{
Larry M. Ebhota1, Osamede Osarobo Ogbeide², Innocent Uduehi Abhulimen³ \\ ${ }^{1}$ Groove Engineering \& Intergrated services Limited, Port-Harcort, Nigeria \\ ${ }^{2}$ Department of Production Engineering, University of Benin, Benin City, Nigeria \\ ${ }^{3}$ Department of Industrial and Production Engineering, Ambrose Alli University, Ekpoma, Nigeria \\ Email: larryebhota@yahoo.com, osarobo.ogbeide@uniben.edu, innocentuduehiabhulimen@gmail.com
}

How to cite this paper: Ebhota, L.M., Ogbeide, O.O. and Abhulimen, I.U. (2021) Prediction and Selection of the Best Process Parameters to Improve Toughness of Mild Steel Welded Joints. Open Access Library Journal, 8: e7743.

https://doi.org/10.4236/oalib.1107743

Received: July 8, 2021

Accepted: August 9, 2021

Published: August 12, 2021

Copyright $\odot 2021$ by author(s) and Open Access Library Inc.

This work is licensed under the Creative Commons Attribution International License (CC BY 4.0).

http://creativecommons.org/licenses/by/4.0/ (c) (i) Open Access

\begin{abstract}
Poor combination of input process parameters has resulted in an innumerable amount of weld failure due to its negative influence on the microstructural and mechanical properties of the welded joints. To improve the welded joint, it is imperative that the material toughness be optimized. The aim of this study is to predict and enhance the toughness of mild steel welded joint using Response Surface Methodology (RSM). $10 \mathrm{~mm}$ mild steel plate was cut into 200 piece coupons measuring $27.5 \times 10 \times 10 \mathrm{~mm}$ for the experiment, after welding of the piece, 100 specimens of $55 \times 10 \times 10 \mathrm{~mm}$ were produced and the experiment was performed 20 times. Charpy impact tester was employed to measure the degree of toughness of the material, and results were analyzed using RSM. The results produced an optimum impact test of 275.514 joules at a desirability value of $95.6 \%$. This optimum impact test was achieved through the use of current of $120.00 \mathrm{amp}$, voltage of 20.00 volt and gas flow rate of $12.00 \mathrm{~L} / \mathrm{min}$. The weld current was found to have a greater influence on the impact strength of the weldment as compared to voltage and gas flow rate at a moderate level.
\end{abstract}

\section{Subject Areas}

Material Experiment

\section{Keywords}

Impact, Weldment, Mild Steel, Specimen

\section{Introduction}

Toughness is usually regarded as the ability of materials to absorb energy before 
fracture, although, failure in welded materials can also arise from resonance (Etin-Osa and Achebo 2017) [1]. The toughness of a material is the amount of impact shock a material can withstand before failure which can be described graphically as the area under stress strain curve. The tougher a material, the better its ability to withstand sudden shock (Achebo and Odinikuku 2015) [2] and (Imhansoloeva et al., 2018) [3]. Usually, the Izod and Charpy test are the most common method of measuring toughness of material. In welding, heat input that aids the joining of metals, can also cause a reduced toughness at welded joint, when an inexperience or poor combinations of process parameters are employed (Mallya and Srinivas 1989) [4], (Mistry, 2016) [5] and (Akande, 2016) [6]. This poor combination of input process parameters has resulted in an innumerable amount of weld failure due to its negative influence on the microstructural and mechanical properties of the welded joint (Etin-Osa and Etin-Osa, 2019) [1]. Mild steel is one of the cheapest metals in the market widely used because of its good microstructural and mechanical properties. It contains up to 0.2 percent carbon by weight and is often used in the building of ships, beams for buildings and bridges. The use of mild steel in production of desired construction and engineering structures can hardly be achieved without a joining process (Achebo, 2012) [7]. Quality and productivity play important role in today's manufacturing market, as it stresses the need for continuous improvement. Nowadays due to very stiff and cut throat competitive market conditions in manufacturing industries, quick failure of mild steel components are not tolerated, thereby necessitating the need to improve the toughness of the material. Usually, excessive or little heat input compromises the toughness of the welded joint. In other to achieve an optimum toughness, deliberate effort is put in place to identify the input process parameters which results in the best toughness (Achebo, 2011) [8]. In time past, numerical analysis of welded materials was carried out, solving by hand (Mallya and Srinivas, 1989) [4]. This procedure was very cumbersome as it took a lot of solving time with a higher error margin, but with the introduction of computer software to handle statistics, simulation, optimizations and predictions, welding operations can now be studies with in-depth knowledge of the causes of failure. Some researchers applied the try and error technique in weld optimization. This technique is time consuming and takes more experimentation, making it less economical. Our aim is to predict and improve the toughness of mild steel material, using the tungsten inert gas (TIG) welding process and response surface methodology.

\section{Materials and Methods}

\subsection{Materials}

This research work was conducted at the Department of Welding and fabrication technology, Petroleum Training Institute (PTI), Warri, Delta State, Nigeria. The Tungsten Inert Gas (TIG) welding method was adopted, thereafter, the samples from the welding process were subjected to impact test. Table 1 presents 
the process parameters employed for the research. The selected input parameters have the upper $(+)$ and lower limits $(-)$. All the materials used in this research were purchased from a local vendor.

\subsection{Weld Penetration Form Factor Measurement}

The $10 \mathrm{~mm}$ mild steel plate was cut into 200 piecescouponsmeasuring $27.5 \times 10$ $\times 10 \mathrm{~mm}$ for the experiment, after welding of the piece, 100 specimens of $55 \times 10$ $\times 10 \mathrm{~mm}$ were produced, the experiment was performed twenty (20) times as presented in Table 2, using five (5) specimens per run. The welded specimen fits into the Charpy impact tester. The welded specimen was a rectangular shaped mild steel plate with measured dimension of $55 \times 10 \times 10 \mathrm{~mm}$ with a V-shaped notch, $2 \mathrm{~mm}$ deep, with 45 angle and $0.25 \mathrm{~mm}$ radius along the base cut in one side. The notch allows for a predetermined crack initiation location as shown in Figure 1.

\section{Results and Discussion}

\subsection{Results}

The study produced twenty experimental runs, each experimental run comprising the current, voltage and gas flow rate, used to join two pieces of mild steel plates measuring $55 \mathrm{~mm} \times 10 \mathrm{~mm} \times 10 \mathrm{~mm}$. The impact test strength, was measured. The responses are shown in Table 2.

According to literature, the difference between the predicted and adjusted $\mathrm{R}^{2}$ must be less than 0.2. In this research, a difference of 0.131 which is less than 0.2 was obtained in Table 3. The adequate Precision of 12.8046 which is used to measures the signal to noise ratio was obtained in our study. Literature states that the ratio should be greater than 4 to be desirable. Since the required condition for the fit statistics has been meet, the model can now be used to navigate the design space.

Table 1. Welding process parameters limits.

\begin{tabular}{ccccc}
\hline Process parameters & Unit & Symbol & Low (-) & High (+) \\
\hline Welding Current & Amp & $\mathrm{I}$ & 120 & 170 \\
Welding Voltage & Volts & $\mathrm{V}$ & 20 & 25 \\
\hline Gas Flow Rate & Lit/mill & F & 12 & 14 \\
\hline & & & $10 \mathrm{~mm}^{\circ}$ \\
\hline
\end{tabular}

Figure 1. Charpy impact test specimen. 
Table 2. Experimental result for the impact test.

\begin{tabular}{|c|c|c|c|c|}
\hline Run & $\begin{array}{l}\text { A: Welding } \\
\text { Current }\end{array}$ & $\begin{array}{l}\text { B: Welding } \\
\text { Voltage }\end{array}$ & $\begin{array}{c}\text { C: Gas Flow } \\
\text { Rate }\end{array}$ & Impact Test \\
\hline & Amp & Volts & Lit/mill & $\mathrm{J}$ \\
\hline 1 & 145 & 22.5 & 13 & 235.144 \\
\hline 2 & 145 & 22.5 & 13 & 227.136 \\
\hline 3 & 187.045 & 22.5 & 13 & 259.168 \\
\hline 4 & 145 & 22.5 & 11.3182 & 257.712 \\
\hline 5 & 170 & 20 & 12 & 234.416 \\
\hline 6 & 145 & 18.2955 & 13 & 230.048 \\
\hline 7 & 170 & 25 & 14 & 265.502 \\
\hline 8 & 120 & 20 & 14 & 235.872 \\
\hline 9 & 170 & 25 & 12 & 243.152 \\
\hline 10 & 120 & 25 & 12 & 270.088 \\
\hline 11 & 120 & 20 & 12 & 272.272 \\
\hline 12 & 102.955 & 22.5 & 13 & 278.096 \\
\hline 13 & 170 & 20 & 14 & 219.128 \\
\hline 14 & 145 & 22.5 & 14.6818 & 232.232 \\
\hline 15 & 145 & 22.5 & 13 & 230.776 \\
\hline 16 & 145 & 22.5 & 13 & 234.072 \\
\hline 17 & 145 & 26.7045 & 13 & 249.704 \\
\hline 18 & 145 & 22.5 & 13 & 238.784 \\
\hline 19 & 120 & 25 & 14 & 261.352 \\
\hline 20 & 145 & 22.5 & 13 & 219.128 \\
\hline
\end{tabular}

Table 3. Fit statistics for the impact test.

\begin{tabular}{cccc}
\hline Std. Dev. & 6.35 & $\mathbf{R}^{2}$ & 0.9354 \\
Mean & 244.69 & Adjusted $\mathbf{R}^{2}$ & 0.8773 \\
C.V. \% & 2.59 & Predicted $\mathrm{R}^{2}$ & 0.7463 \\
& & Adeq Precision & 12.8046 \\
\hline
\end{tabular}

Table 4 presents the sum of squares which is a Type III-Partial, 16.10 was obtained as the Model F-value which describe a significant model. This means that there is only a $0.01 \%$ chance that an F-value this large manifest due to noise. The $\mathrm{P}$-values less than 0.0500 shows that the model terms are significant. In this case $\mathrm{A}, \mathrm{B}, \mathrm{C}, \mathrm{AC}, \mathrm{AB}, \mathrm{BC}, \mathrm{A}^{2}$ and $\mathrm{C}^{2}$ obtained a P-val less than 0.05. This would increase the accuracy of our mathematical model in predicting the responses. 
Table 4. ANOVA table for impact test.

\begin{tabular}{|c|c|c|c|c|c|c|}
\hline Source & $\begin{array}{l}\text { Sum of } \\
\text { Squares }\end{array}$ & $\mathrm{df}$ & $\begin{array}{l}\text { Mean } \\
\text { Square }\end{array}$ & F-value & p-value & \\
\hline Model & 5836.6 & 9 & 648.51 & 16.1 & $<0.0001$ & significant \\
\hline $\begin{array}{l}\text { A-Welding } \\
\text { Current }\end{array}$ & 873.47 & 1 & 873.47 & 21.68 & 0.0009 & \\
\hline $\begin{array}{l}\text { B-Welding } \\
\text { Voltage }\end{array}$ & 909.73 & 1 & 909.73 & 22.58 & 0.0008 & \\
\hline $\begin{array}{c}\text { C-Gas Flow } \\
\text { Rate }\end{array}$ & 479.55 & 1 & 479.55 & 11.9 & 0.0062 & \\
\hline $\mathrm{AB}$ & 126.51 & 1 & 126.51 & 3.14 & 0.1068 & \\
\hline $\mathrm{AC}$ & 340.57 & 1 & 340.57 & 8.45 & 0.0156 & \\
\hline $\mathrm{BC}$ & 533.04 & 1 & 533.04 & 13.23 & 0.0046 & \\
\hline $\mathrm{A}^{2}$ & 2399.52 & 1 & 2399.52 & 59.56 & $<0.0001$ & \\
\hline $\mathrm{B}^{2}$ & 107.94 & 1 & 107.94 & 2.68 & 0.1327 & \\
\hline $\mathrm{C}^{2}$ & 296.85 & 1 & 296.85 & 7.37 & 0.0218 & \\
\hline Residual & 402.85 & 10 & 40.28 & & & \\
\hline Lack of Fit & 159.88 & 5 & 31.98 & 0.658 & 0.6714 & $\begin{array}{c}\text { not } \\
\text { significant }\end{array}$ \\
\hline Pure Error & 242.97 & 5 & 48.59 & & & \\
\hline Cor Total & 6239.45 & 19 & & & & \\
\hline
\end{tabular}

Based on the P-value obtained in Table 4, Equation (1) was mathematically modelled in terms of coded factors for predicting the impact test (IT). For minimal prediction error, more factors with $\mathrm{P}$-value less than $5 \%$ should be included in the equation.

$$
\begin{aligned}
\mathrm{IT}= & 230.91-8.00 \mathrm{~A}-5.93 \mathrm{~B}-5.93 \mathrm{C}+3.98 \mathrm{AB}+6.52 \mathrm{AC} \\
& +8.16 \mathrm{BC}+12.90 \mathrm{~A}^{2}+2.74 \mathrm{~B}^{2}+4.54 \mathrm{C}^{2}
\end{aligned}
$$

where, $\mathrm{A}=$ voltage, $\mathrm{B}=$ current, $\mathrm{C}=$ gas flow rate.

The plot in Figure 2 was used to examine the reliability of future prediction based on the response obtained from the actual vs predicted impact. The blue square dots indicates the lowest limits of 219.128 joules while the red square dots, shows the maximum impact of 278.096 joules absorbed by the specimen.

The 3D surface plot was employed to examine the effect of the welding voltage and current on the impact absorption of mild steel specimen. At a gas flow rate of $13 \mathrm{~L} / \mathrm{min}$, the current and voltage could be varied to obtain the $3 \mathrm{D}$ surface plot architect presented in Figure 3. To target above the known predicted value, aim at the wine dot above the 3D mat while to predict below the known prediction value, aim at the dotted peach below. 


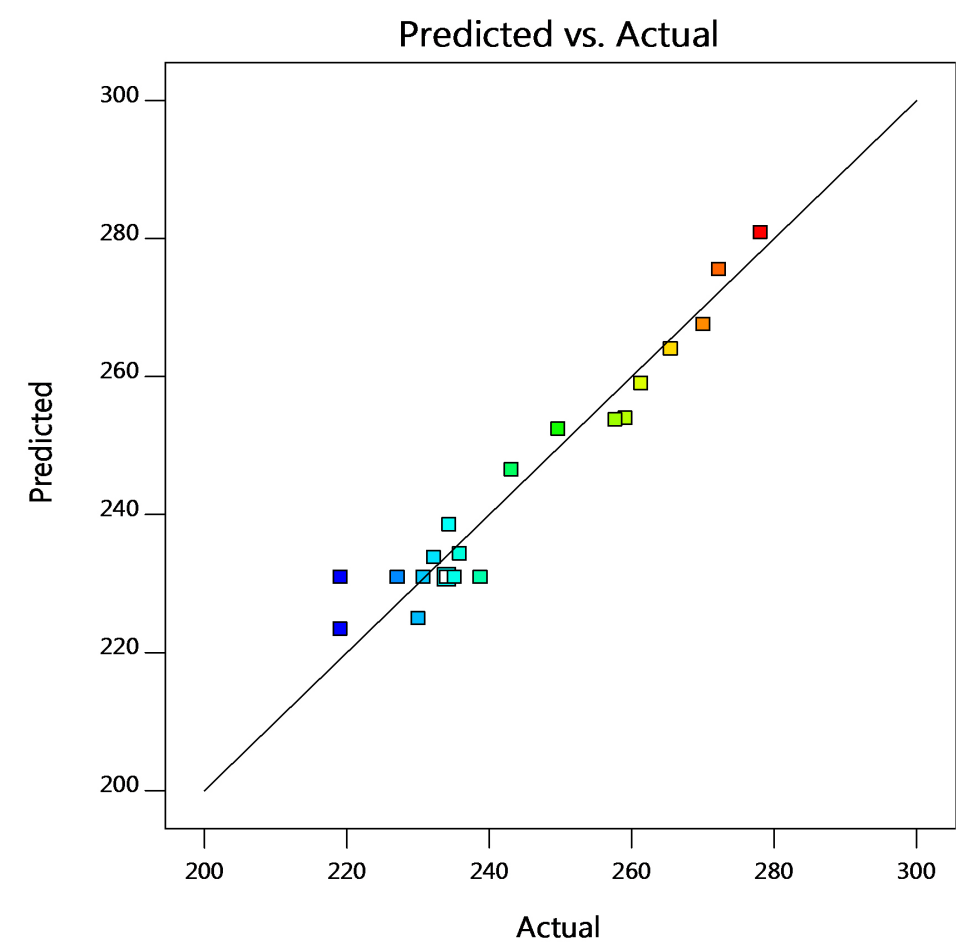

Figure 2. Reliability plot of observed versus predicted impact responses.

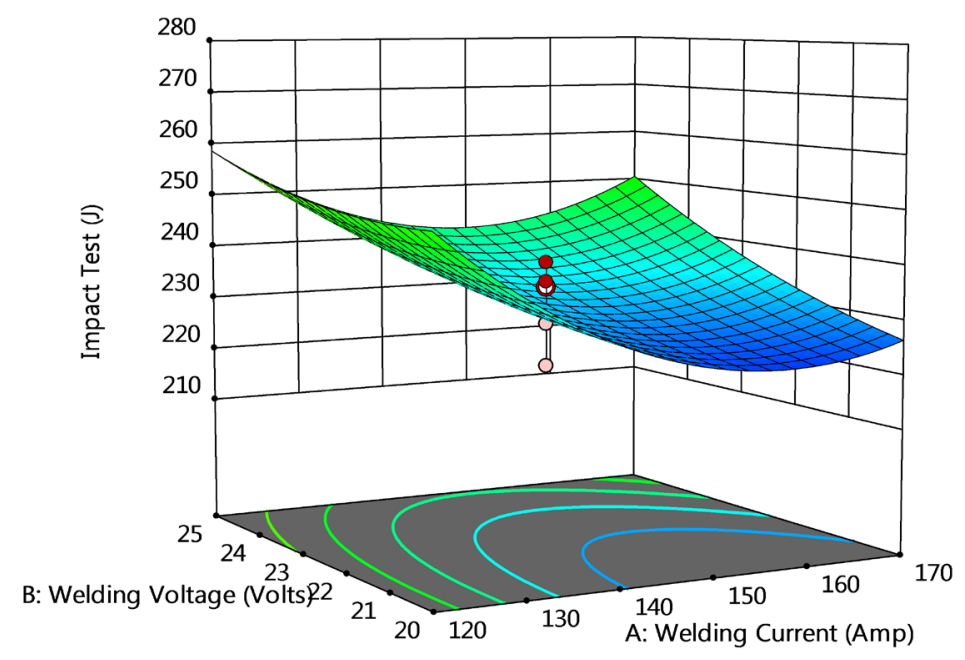

Figure 3. 3D surface plot for impact test.

The interphase in Figure 4 with the maximization target for the impact test, was employed to optimize the response. In the numerical optimization phase, design expert was instructed to maximize the impact test, while also determining the optimum value of voltage, current and gas flow rate.

Table 5 shows five (5) out of the eighteen (18) optimal solutions obtained from the settings made in Figure 4.

Finally, from the optimal solution, the contour plots showing the impact response variable of voltage and current at a gas flow rate of $12 \mathrm{~L} / \mathrm{min}$, against the optimized value of the input variable is presented in Figure 5. 
Table 5. Optimal solutions of numerical optimization model.

\begin{tabular}{ccccccc}
\hline Number & $\begin{array}{c}\text { Welding } \\
\text { Current }\end{array}$ & $\begin{array}{c}\text { Welding } \\
\text { Voltage }\end{array}$ & $\begin{array}{c}\text { Gas Flow } \\
\text { Rate }\end{array}$ & $\begin{array}{c}\text { Impact } \\
\text { Test }\end{array}$ & Desirability & \\
\hline 1 & $\mathbf{1 2 0 . 0 0 0}$ & $\mathbf{2 0 . 0 0 0}$ & $\mathbf{1 2 . 0 0 0}$ & $\mathbf{2 7 5 . 5 1 4}$ & $\mathbf{0 . 9 5 6}$ & Selected \\
2 & 120.000 & 20.036 & 12.000 & 275.378 & 0.954 & \\
3 & 120.010 & 20.000 & 12.007 & 275.285 & 0.952 & \\
4 & 120.177 & 20.000 & 12.000 & 275.201 & 0.951 & \\
5 & 120.000 & 20.119 & 12.000 & 275.069 & 0.949 & \\
\hline
\end{tabular}

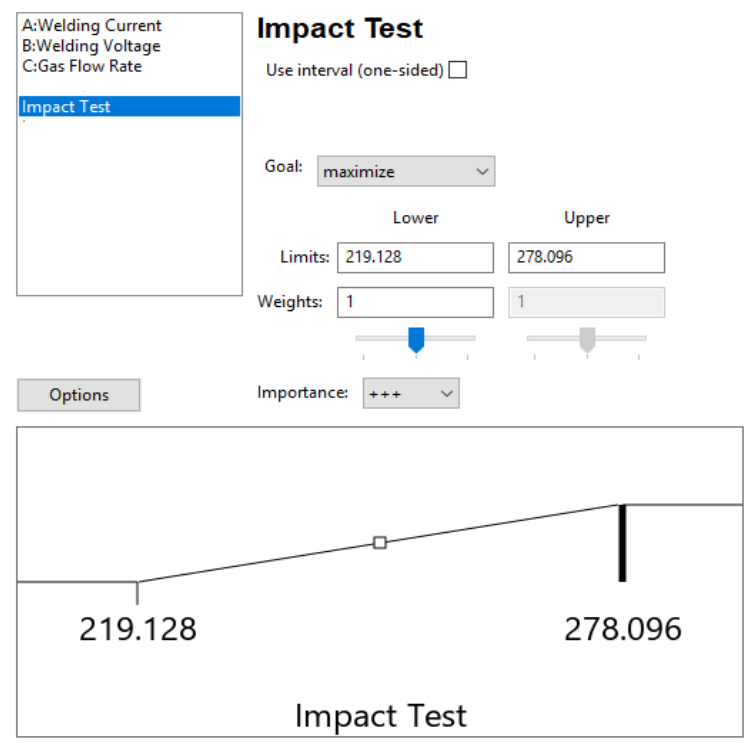

Figure 4. Interphase of numerical optimization of impact test.

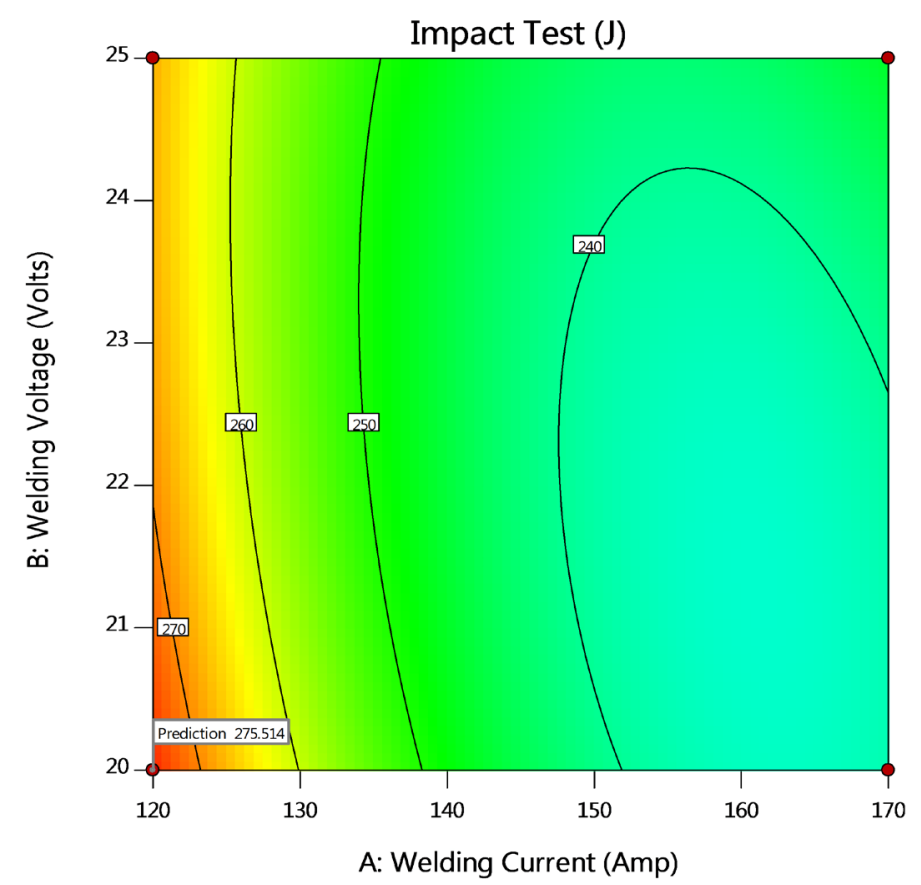

Figure 5. Predicting weld impact test using contour plot. 


\subsection{Discussion}

The Fit Statistics for the Impact Test in Table 3, shows that The $\mathrm{R}^{2}$ value of 0.9354 , Predicted $R^{2}$ of 0.7463 and an Adjusted $R^{2}$ of 0.8773 were obtained. The difference between the predicted and adjusted $\mathrm{R}^{2}$ of less than 0.2 was recorded, indicating a significant model. With an adequate Precision of 12.805 , demonstrating a significant model. It meant that the mathematical model in Equation (1), can be employed to navigate the design space. In Figure 2, the reliability plotdeveloped was employed to compare the predicted response values obtained from using Equation (1) to that of the actual response. Based on the plot, it was observed that a positive linear relationship existed between the predicted and the actual response, with majority of the points clustering along the stright line. This indicates a good prediction model which can be employed for unknown prediction of the impact test. Figure 3 shows the 3D surface plot for the impact test with the lower impact test area denoted by the blue region and the green region representing the area with the highest impact strength. The 3D surface plot was used to determine the effect of current and voltage at a gas flow rate of $13 \mathrm{~L} / \mathrm{min}$ on the impact test responses. From Figure 3, it was noticed that only current had a very strong effect on the response. Optimization was initiated using the interphase presented in Figure 4 with the lowest and highest impact of 219.128 and 278.096 being the optimization boundary space. Five (5) optimal results were selected as shown in Table 5 with the best having a current of $120.00 \mathrm{Amp}$, voltage of 20.00 volt and gas flow rate of $12.00 \mathrm{~L} / \mathrm{min}$, to produce a weld material with impact test of 275.514 joules at a desirability value of $95.6 \%$. To further understand better, the effect of the process parameters on the response, Figure 5 was employed. This plot also known as the contour plot, shows that at a constant gas flow rate of $12 \mathrm{~L} / \mathrm{mm}$, quality weld can be achieved with voltage ranging between 20 - 25 volts, and a current range of about 120 - $125 \mathrm{amp}$, represented the red area on the plot in Figure 5. It shows that current has a significant effect on either increasing or reducing the material toughness. From the contour plot, it was noticed that lower current between 120 - 125 amp produced better impact test as compared with higher current input of $170 \mathrm{amp}$.

\section{Conclusion}

In this study a mathematical model for predicting impact test in Equation (1) has been developed with and an optimum impact test of 275.514 joules at a desirability value of $95.6 \%$. This optimum impact test was achieved through the use of current of $120.00 \mathrm{amp}$, voltage of 20.00 volt and gas flow rate of 12.00 $\mathrm{L} / \mathrm{min}$. The weld current was found to have a great influence on the impact strength of the weldment as compared to voltage and gas flow rate at a moderate level.

\section{Conflicts of Interest}

The authors declare no conflicts of interest. 


\section{References}

[1] Etin-Osa, C.E. and Achebo, J.I. (2017) Analysis of Optimum Butt Welded Joint for Mild Steel Components Using FEM (ANSYS). American Journal of Naval Architecture and Marine Engineering, 2, 91-98.

http://www.sciencepublishinggroup.com/j/ajname

[2] Achebo, J. and Odinikuku, W. (2015) Optimization of Gas Metal Arc Welding Process Parameters Using Standard Deviation (SDV) and Multi-Objective Optimization on the Basis of Ratio Analysis (MOORA). Journal of Minerals and Materials Characterization and Engineering, 3, 298-308.

https://doi.org/10.4236/jmmce.2015.34032

[3] Imhansoloeva, N.A., Achebo, J.I., Obahiagbon, K.O., Osarenmwinda, J.O. and Etin-Osa, C.E. (2018) Optimization of the Deposition Rate of Tungsten Inert Gas Mild Steel Using Response Surface Methodology. Engineering, 10, 784-804. https://doi.org/10.4236/eng.2018.1011055

[4] Zeman, M. (2009) Assessment of Weldability of WELDOX 1100 High-Strength Quenched and Tempered Steel. Welding International, 23, 73-82.

https://doi.org/10.1080/09507110802349122

[5] Mistry, P.J. (2016) Effect of Process Parameters on Bead Geometry and Shape Relationship of Gas Metal Arc Weldments. International Journal of Advanced Research in Mechanical Engineering \& Technology, 2, 24-27.

[6] Akande, B.F., Debo-Saiye, B., Akinjobi, S.D., Alao, T.O. and Akinrogunde, O.O. (2016) Causes, Effects and Remedies to the incessant Building Collapse in Lagos State, Nigeria. International Journal of Basic \& Applied Sciences IJBAS-IJENS, 16, 15-30.

[7] Achebo, J.I. (2012) Numerical Computation of Melting Efficiency of Aluminum Alloy 5083 during $\mathrm{CO}_{2}$ Laser Welding Process. In: Ochsner, A., et al, Eds., Materials with Complex Behaviour II, Springer-Verlag, Berlin. https://doi.org/10.1007/978-3-642-22700-4_37

[8] Achebo, J.I. (2012) Complex Behavior of Forces Influencing Molten Weld Metal Flow Based on Static Force Balance Theory. Physics Procedia, 25, 317-324. https://doi.org/10.1016/j.phpro.2012.03.090 